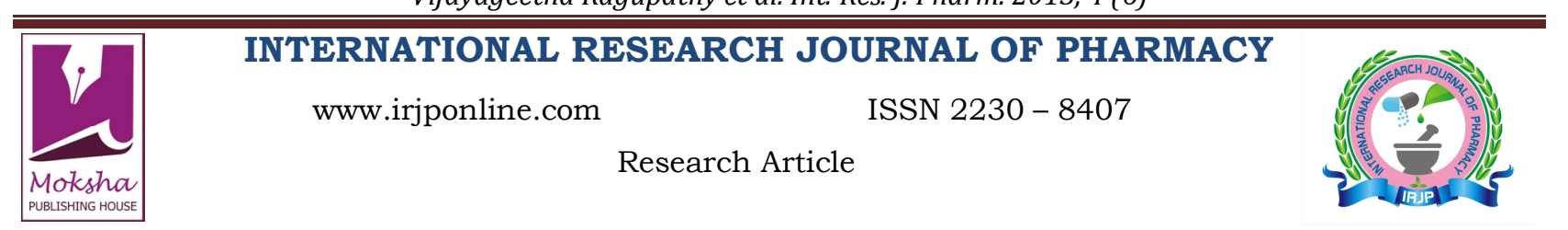

\title{
SIMULTANEOUS SPECTROPHOTOMETRIC DETERMINATION OF DIACEREIN AND CELECOXIB IN CAPSULES BY CHEMOMETRIC METHODS
}

\author{
Vijayageetha Ragupathy*1, Shantha $\operatorname{Arcot}^{2}$ \\ ${ }^{1}$ Department of Pharmaceutical Analysis, Faculty of Pharmacy, C.L Baid Metha College of Pharmacy, Thoraipakkam, \\ Chennai-600 097, Tamil Nadu, India \\ ${ }^{2}$ HOD, Department of Pharmaceutical Analysis, C.L Baid Metha College of Pharmacy, Thoraipakkam, Chennai-600 097, \\ Tamil Nadu, India \\ *Corresponding Author Email: venista7@gmail.com
}

Article Received on: 10/03/13 Revised on: 01/04/13 Approved for publication: 11/05/13

DOI: $10.7897 / 2230-8407.04652$

IRJP is an official publication of Moksha Publishing House. Website: www.mokshaph.com

(C) All rights reserved.

\section{ABSTRACT}

Simultaneous spectrophotometric determination of diacerein and celecoxib was performed by partial least-squares (PLS) and principal component regression (PCR) methods do not require any priori graphical treatment of the overlapping spectra of two drugs in the mixture. The absorbance values in the UV-Vis spectra were measured for the 64 wavelength points (from 225-288) in the spectral region 200-400 nm considering the intervals of $1 \mathrm{~nm}$. The calibration range was found to be $2-10 \mu \mathrm{g} / \mathrm{ml}$ for diacerein, 4-20 $\mu \mathrm{g} / \mathrm{ml}$ for celecoxib with a correlation coefficient of 0.9999(PLS), 0.9998(PCR) for diacerein and 0.9999(PLS) ,0.9999(PCR) for celecoxib. The validation of the multivariate methods was realized by analyzing the synthetic mixtures of diacerein and celecoxib. The numerical calculations were performed with the 'Unscrambler $10.1 \mathrm{X}$ ' software. The chemometrics analysis methods were satisfactorily applied to the simultaneous determination of diacerein and celecoxib in the pharmaceutical formulation.

Key words: celecoxib, chemometrics, diacerein, spectrophotometry, partial least square, principal component regression.

\section{INTRODUCTION}

Diacerein (DIA) is chemically 1, 8-Diacetoxy-3carboxyanthraquinone which is used as an analgesic, antipyretic and anti inflammatory Agent ${ }^{1-2}$. Celecoxib (CELE) chemically described as 4-[5-(4-methylphenyl)-3(trifluoromethyl) pyrazol-1-yl]benzeneslfonamide is a selective cyclooxygenase-2 (COX-2) inhibitor approved for relief of the signs and symptoms of inflammation associated with rheumatoid arthritis and osteoarthritis ${ }^{3}$. From the literature survey it was found that HPLC and spectrophotometric methods are available for the determination of diacerein ${ }^{4-8}$ and celecoxib ${ }^{9-16}$ alone and combined dosage form with other drugs but there is no method available for the simultaneous estimation of diacerein and celecoxib in combined dosage form by chemometrics. So there is a need for a method capable of simultaneous estimation of diacerein and celecoxib in pharmaceuticals by chemometric methods.

The aim of this paper is to investigate the ability of PLS and PCR methods to quantify binary mixture of DIA and CELE with overlapping spectra and to apply the optimized models in pharmaceutical preparations. The proposed methods are simple, sensitive and reproducible method for the simultaneous estimation of diacerein and celecoxib from combined dosage form.

In recent years, multivariate calibrations, such as classical least-squares (CLS), inverse least-squares (ILS), principal component regression (PCR) and partial least-squares (PLS) are started to apply to the analysis of the analytical data obtained in all the instrumentations ${ }^{17-18}$. The same methods and their algorithms (NIPALS) have been applied to the simultaneous spectrophotometric determination of drugs in the pharmaceutical formulation containing two or more compounds with overlapping spectra. On the other hand the chemometric calibration methods as those enumerated above have been used extensively in quantitative spectral analysis to get selective information from unselective data. The main advantages of these techniques are the following: a higher speed of processing data concerning the values of concentrations and absorbance of compounds with strongly overlapping spectra, the errors of calibration model are minimised by measuring the absorbance values at many points in the wavelength range of the zero-order and derivative spectra. Analytical methods using multivariate calibrations and their applications include the spectrophotometric, chromatographic and electrochemical for determinations of analytes in the mixtures.

\section{MATERIALS \& METHODS}

\section{Instruments and software}

Digitized UV/VIS absorbency spectra were collected using a UV-visible spectrometer 2300 Techcomp with $1 \mathrm{~cm}$ quartz cells. The data acquisition was made with UV solutions software at a scan rate of $1000 \mathrm{~nm} \mathrm{~min}-1$ and the slit width of $2 \mathrm{~nm}$. The UV spectra of mixtures were recorded over the wavelength 225-288 nm with one data point per nm. All spectral measurements were performed using blank solution as a reference. Partial least squares regression, and principal component regression were used for chemometric analysis of data. For all calculations Unscrambler for windows (Version 10.1 X) was used.

\section{Pharmaceutical tablet formulations}

A commercial pharmaceutical formulation (OSTIGARD 100) capsule containing $50 \mathrm{mg}$ of DIA and $100 \mathrm{mg}$ of CELE was analysed by the proposed chemometric methods.

\section{Standard solutions}

Stock solutions of Diacerein and celecoxib of $10 \mathrm{mg}$ were prepared in $100 \mathrm{ml}$ volumetric flasks with methanol. The training set containing $2-10 \mu \mathrm{g} / \mathrm{ml}$ diacerein and $4-20 \mu \mathrm{g} / \mathrm{ml}$ celecoxib working standard solutions were prepared by diluting the stock solutions for each drug according to its linear calibration range. Two sets of standard solutions were 
prepared, the calibration set contained 25 standard solutions and the prediction set contained 9 standard solutions. To a series of $10 \mathrm{ml}$ volumetric flasks, aliquots of diacerein and celecoxib solutions, containing appropriate amount of these drugs in the range of calibrations, were added and then the solutions were diluted to $10 \mathrm{ml}$ with methanol. UV spectra of the mixtures were recorded in the wavelength range 225-288 $\mathrm{nm}$ versus a solvent blank, and digitized absorbance was sampled at $1 \mathrm{~nm}$ intervals. All the solutions were prepared freshly and were protected from light.

\section{Sample preparations}

Twenty capsules were accurately weighed and powdered in a mortar. An amount of the powder equivalent was weighed and dissolved in methanol in $100 \mathrm{ml}$ calibrated flasks. $20 \mathrm{ml}$ of methanol was added and ultra sonicated for 25 minutes and the volume was made up to100 $\mathrm{ml}$ with methanol and shake well. Then, the solution was filtered through what man filter paper No. 41 and the residue was washed three times with 10 $\mathrm{ml}$ of solvent, and then the volume was completed to $100 \mathrm{ml}$ with methanol. The resulting solution was diluted to $1: 2$ in a $100 \mathrm{ml}$ calibrated flasks. Both techniques were applied to the prepared sample solutions.

TABLE 1 COMPOSITION OF CALIBRATION SET (TRAINING SET) FOR PLS AND PCR METHODS

\begin{tabular}{|c|c|c|c|c|c|c|}
\hline \multirow[t]{3}{*}{ S.NO } & \multicolumn{3}{|c|}{ Diacerein } & \multicolumn{3}{|c|}{ Celecoxib } \\
\hline & \multirow[t]{2}{*}{ Reference $\mu \mathrm{g} / \mathrm{ml}$} & \multicolumn{2}{|c|}{ Predicted $\mu \mathrm{g} / \mathrm{ml}$} & \multirow[t]{2}{*}{ Reference $\mu \mathrm{g} / \mathrm{ml}$} & \multicolumn{2}{|c|}{ Predicted $\mu \mathrm{g} / \mathrm{ml}$} \\
\hline & & PLS & PCR & & PLS & PCR \\
\hline 1 & 2 & 2.03 & 2.03 & 4.00 & 4.08 & 4.08 \\
\hline 2 & 2 & 2.02 & 2.02 & 8.00 & 7.97 & 7.97 \\
\hline 3 & 2 & 2.01 & 2.01 & 12.00 & 11.96 & 11.96 \\
\hline 4 & 2 & 2.00 & 2.00 & 16.00 & 16.15 & 16.15 \\
\hline 5 & 2 & 1.99 & 1.99 & 20.00 & 19.94 & 19.94 \\
\hline 6 & 4 & 4.08 & 4.08 & 4.00 & 4.07 & 4.07 \\
\hline 7 & 4 & 4.06 & 4.06 & 8.00 & 7.96 & 7.96 \\
\hline 8 & 4 & 4.05 & 4.05 & 12.00 & 11.95 & 11.95 \\
\hline 9 & 4 & 4.04 & 4.04 & 16.00 & 16.14 & 16.14 \\
\hline 10 & 4 & 4.03 & 4.03 & 20.00 & 19.94 & 19.94 \\
\hline 11 & 6 & 5.97 & 5.97 & 4.00 & 4.06 & 4.06 \\
\hline 12 & 6 & 5.96 & 5.96 & 8.00 & 7.96 & 7.96 \\
\hline 13 & 6 & 5.95 & 5.95 & 12.00 & 11.95 & 11.95 \\
\hline 14 & 6 & 5.94 & 5.94 & 16.00 & 16.14 & 16.14 \\
\hline 15 & 6 & 5.93 & 5.93 & 20.00 & 19.93 & 19.93 \\
\hline 16 & 8 & 8.11 & 8.11 & 4.00 & 4.06 & 4.06 \\
\hline 17 & 8 & 8.10 & 8.10 & 8.00 & 7.95 & 7.95 \\
\hline 18 & 8 & 8.09 & 8.09 & 12.00 & 11.94 & 11.94 \\
\hline 19 & 8 & 8.08 & 8.08 & 16.00 & 16.13 & 16.13 \\
\hline 20 & 8 & 8.07 & 8.07 & 20.00 & 19.92 & 19.92 \\
\hline 21 & 10 & 9.96 & 9.96 & 4.00 & 4.05 & 4.05 \\
\hline 22 & 10 & 9.94 & 9.94 & 8.00 & 7.94 & 7.94 \\
\hline 23 & 10 & 9.93 & 9.93 & 12.00 & 11.93 & 11.93 \\
\hline 24 & 10 & 9.92 & 9.92 & 16.00 & 16.12 & 16.12 \\
\hline 25 & 10 & 9.91 & 9.91 & 20.00 & 19.91 & 19.91 \\
\hline
\end{tabular}

TABLE 2 COMPOSITION OF VALIDATION (PREDICTION SET) FOR PLS AND PCR METHODS

\begin{tabular}{|c|c|c|c|c|c|c|}
\hline \multirow[t]{3}{*}{ S.NO } & \multicolumn{3}{|c|}{ Diacerein } & \multicolumn{3}{|c|}{ Celecoxib } \\
\hline & \multirow[t]{2}{*}{ Reference $\mu \mathrm{g} / \mathrm{ml}$} & \multicolumn{2}{|c|}{ Predicted $\mu \mathrm{g} / \mathrm{ml}$} & \multirow[t]{2}{*}{ Reference $\mu \mathrm{g} / \mathrm{ml}$} & \multicolumn{2}{|c|}{ Predicted $\mu \mathrm{g} / \mathrm{ml}$} \\
\hline & & PLS & PCR & & PLS & PCR \\
\hline 1 & 3 & 3.09 & 3.09 & 6.00 & 6.07 & 6.07 \\
\hline 2 & 3 & 3.08 & 3.08 & 10.00 & 9.96 & 9.96 \\
\hline 3 & 3 & 3.07 & 3.07 & 14.00 & 14.25 & 14.25 \\
\hline 4 & 5 & 4.97 & 4.97 & 6.00 & 6.06 & 6.06 \\
\hline 5 & 5 & 4.96 & 4.96 & 10.00 & 9.96 & 9.96 \\
\hline 6 & 5 & 4.94 & 4.94 & 14.00 & 14.25 & 14.25 \\
\hline 7 & 7 & 7.01 & 7.01 & 6.00 & 6.06 & 6.06 \\
\hline 8 & 7 & 7.00 & 7.00 & 10.00 & 9.95 & 9.95 \\
\hline 9 & 7 & 6.99 & 6.99 & 14.00 & 14.24 & 14.24 \\
\hline
\end{tabular}

TABLE 3 SUMMARY OF STATISTICS IN PLS AND PCR METHODS

\begin{tabular}{|c|c|c|c|c|c|c|c|c|c|c|}
\hline \multirow[t]{2}{*}{ Drug } & \multicolumn{2}{|c|}{ RMSEP } & \multicolumn{2}{|c|}{ RMSEC } & \multicolumn{2}{|c|}{$r^{2}$} & \multicolumn{2}{|c|}{ Intercept } & \multicolumn{2}{|c|}{ Slope } \\
\hline & PLS & PCR & PLS & PCR & PLS & PCR & PLS & PCR & PLS & PCR \\
\hline DIA & 0.0546 & 0.0546 & 0.0623 & 0.0623 & 0.9999 & 0.9998 & 0.0422 & 0.0422 & 0.9941 & 0.9941 \\
\hline CELE & 0.0148 & 0.0148 & 0.082 & 0.082 & 0.9999 & 0.9999 & 0.0377 & 0.0377 & 0.9976 & 0.9976 \\
\hline
\end{tabular}

Dia-diacerein, Cele- celecoxib, RMSEP-Root mean square error of prediction, RMSEC-Root mean square error of calibration and ${ }^{2-}$ Correlation coefficient.

TABLE 4 ANALYSIS OF TABLET FORMULATION

\begin{tabular}{|c|c|c|c|}
\hline Formulation & Label claim & PLS mg/cap found* & PCR mg/cap found* \\
\hline OSTIGARD 100 & Dia 50mg & 49.66 & 49.67 \\
\cline { 2 - 4 } & Cele 100 mg & 99.74 & 99.75 \\
\hline
\end{tabular}

*Each value is a mean of six readings 
TABLE 5 PRECISION DATA

\begin{tabular}{|c|c|c|c|c|c|c|c|c|}
\hline \multirow[b]{3}{*}{ S.NO } & \multicolumn{4}{|c|}{ System precision } & \multicolumn{4}{|c|}{ Method precision } \\
\hline & \multicolumn{2}{|c|}{ Diacerein } & \multicolumn{2}{|c|}{ Celecoxib } & \multicolumn{2}{|c|}{ Diacerein } & \multicolumn{2}{|c|}{ Celecoxib } \\
\hline & PLS & PCR & PLS & PCR & $\begin{array}{c}\text { PLS \% } \\
\text { purity }\end{array}$ & $\begin{array}{c}\text { PCR \% } \\
\text { purity }\end{array}$ & $\begin{array}{c}\text { PLS \% } \\
\text { purity }\end{array}$ & $\begin{array}{l}\text { PCR\% } \\
\text { purity }\end{array}$ \\
\hline 1. & 5.95 & 5.95 & 11.95 & 11.95 & 99.48 & 99.48 & 99.91 & 99.91 \\
\hline 2. & 5.94 & 5.94 & 11.92 & 11.92 & 99.05 & 99.05 & 99.47 & 99.47 \\
\hline 3. & 5.95 & 5.95 & 11.95 & 11.95 & 99.59 & 99.59 & 100.02 & 100.02 \\
\hline 4. & 5.96 & 5.96 & 11.97 & 11.97 & 99.65 & 99.65 & 100.08 & 100.08 \\
\hline 5. & 5.95 & 5.95 & 11.95 & 11.95 & 99.13 & 99.13 & 99.55 & 99.55 \\
\hline 6. & 5.96 & 5.96 & 11.97 & 11.97 & 99.39 & 99.39 & 99.81 & 99.81 \\
\hline Mean & 5.95 & 5.95 & 11.98 & 11.98 & 99.38 & 99.38 & 99.81 & 99.81 \\
\hline S.D & 0.0087 & 0.0087 & 0.02 & 0.02 & 0.2460 & 0.2460 & 0.2471 & 0.2471 \\
\hline$\%$ RSD & 0.1462 & 0.1462 & 0.15 & 0.15 & 0.2475 & 0.2475 & 0.2475 & 0.2475 \\
\hline
\end{tabular}

TABLE 6 RECOVERY STUDIES

\begin{tabular}{|c|c|c|c|c|c|c|c|c|c|c|}
\hline \multirow{2}{*}{$\begin{array}{c}\text { \% of } \\
\text { Target }\end{array}$} & \multicolumn{5}{|c|}{ Diacerein } & \multicolumn{5}{|c|}{ Celecoxib } \\
\hline & \multicolumn{3}{|c|}{ PLS } & \multicolumn{2}{|c|}{ PCR } & \multicolumn{3}{|c|}{ PLS } & \multicolumn{2}{|c|}{ PCR } \\
\hline \multirow{7}{*}{80} & $\begin{array}{c}\text { Added } \\
\text { mg }\end{array}$ & $\begin{array}{c}\text { Found } \\
\text { mg }\end{array}$ & $\begin{array}{c}\% \\
\text { Recovery } \\
\end{array}$ & $\begin{array}{c}\text { Found } \\
\text { mg }\end{array}$ & $\begin{array}{c}\% \\
\text { Recovery } \\
\end{array}$ & $\begin{array}{c}\text { Added } \\
\text { mg }\end{array}$ & $\begin{array}{c}\text { Found } \\
\text { mg }\end{array}$ & $\begin{array}{c}\% \\
\text { Recovery } \\
\end{array}$ & $\begin{array}{c}\text { Found } \\
\text { mg }\end{array}$ & $\begin{array}{c}\% \\
\text { Recovery } \\
\end{array}$ \\
\hline & 4.8 & 4.75 & 99.03 & 4.75 & 99.03 & 10.00 & 9.99 & 99.9 & 9.99 & 99.9 \\
\hline & 4.8 & 4.76 & 99.14 & 4.76 & 99.14 & 10.00 & 9.96 & 99.6 & 9.96 & 99.6 \\
\hline & 4.8 & 4.73 & 98.53 & 4.73 & 98.53 & 10.00 & 10.01 & 100.1 & 10.01 & 100.1 \\
\hline & \multirow{3}{*}{$\begin{array}{c}\text { Mean } \\
\text { SD } \\
\% \text { RSD }\end{array}$} & 4.75 & 98.90 & 4.75 & 98.90 & \multirow{3}{*}{$\begin{array}{l}\text { Mean } \\
\text { SD } \\
\% \text { RSD }\end{array}$} & 9.98 & 99.8 & 9.986 & 99.86 \\
\hline & & 0.0152 & 0.32 & 0.0152 & 0.32 & & 0.025 & 0.32 & 0.025 & 0.32 \\
\hline & & 0.3218 & 0.33 & 0.3218 & 0.33 & & 0.252 & 0.33 & 0.252 & 0.33 \\
\hline \multirow[t]{6}{*}{100} & 6 & 5.93 & 98.76 & 5.93 & 98.76 & 12.00 & 11.90 & 99.18 & 11.90 & 99.18 \\
\hline & 6 & 5.94 & 99.02 & 5.94 & 99.02 & 12.00 & 11.93 & 99.44 & 11.93 & 99.44 \\
\hline & 6 & 5.91 & 98.51 & 5.91 & 98.51 & 12.00 & 11.87 & 98.93 & 11.87 & 98.93 \\
\hline & \multirow{3}{*}{$\begin{array}{l}\text { Mean } \\
\text { SD } \\
\% \text { RSD }\end{array}$} & 5.926 & 98.76 & 5.926 & 98.76 & \multirow{3}{*}{$\begin{array}{c}\text { Mean } \\
\text { SD } \\
\% \text { RSD }\end{array}$} & 11.9 & 99.19 & 11.9 & 99.19 \\
\hline & & 0.0152 & 0.25 & 0.0152 & 0.25 & & 0.03 & 0.25 & 0.03 & 0.25 \\
\hline & & 0.2577 & 0.26 & 0.2577 & 0.26 & & 0.252 & 0.26 & 0.252 & 0.26 \\
\hline \multirow[t]{6}{*}{120} & 7.2 & 7.15 & 99.30 & 7.15 & 99.30 & 14.00 & 14.36 & 102.57 & 14.36 & 102.57 \\
\hline & 7.2 & 7.13 & 98.98 & 7.13 & 98.98 & 14.00 & 14.31 & 102.24 & 14.31 & 102.24 \\
\hline & 7.2 & 7.11 & 98.81 & 7.11 & 98.81 & 14.00 & 14.29 & 102.07 & 14.29 & 102.07 \\
\hline & \multirow{3}{*}{$\begin{array}{c}\text { Mean } \\
\text { SD } \\
\% \text { RSD }\end{array}$} & 7.13 & 99.03 & 7.13 & 99.03 & \multirow{3}{*}{$\begin{array}{l}\text { Mean } \\
\text { SD } \\
\% \text { RSD }\end{array}$} & 14.32 & 102.30 & 14.32 & 102.30 \\
\hline & & 0.02 & 0.25 & 0.02 & 0.25 & & 0.036 & 0.26 & 0.036 & 0.26 \\
\hline & & 0.2805 & 0.25 & 0.2805 & 0.25 & & 0.251 & 0.25 & 0.251 & 0.248 \\
\hline
\end{tabular}

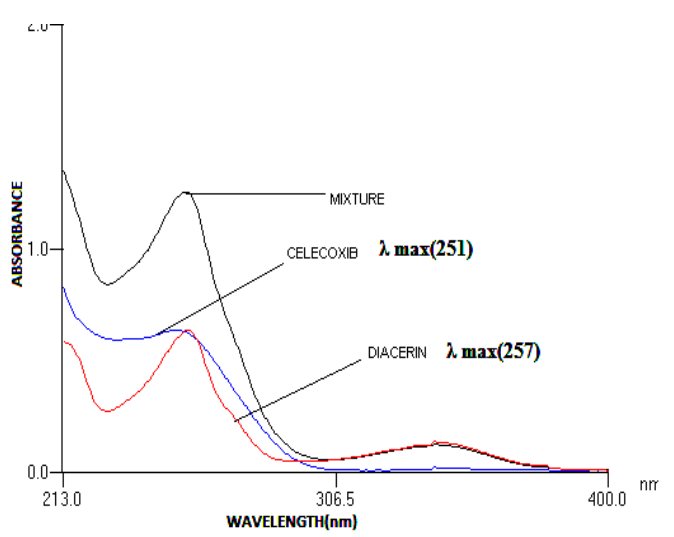

Figure 1 Overlaid UV spectra of Diacerein, Celecoxib and Mixture

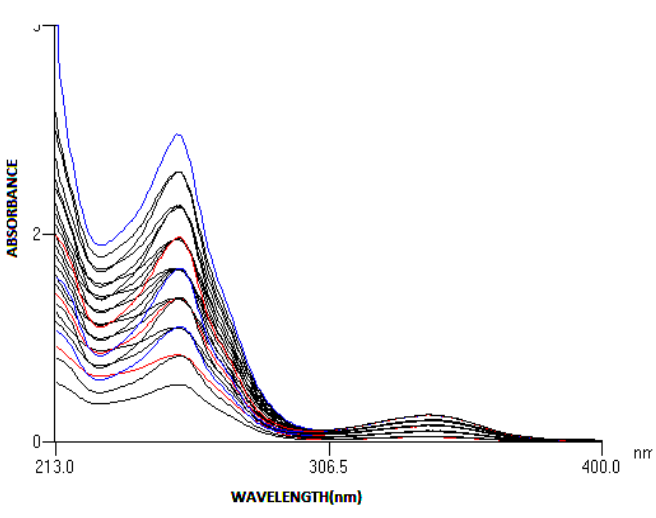

Figure 2 Calibration spectra of Diacerein and Celecoxib 


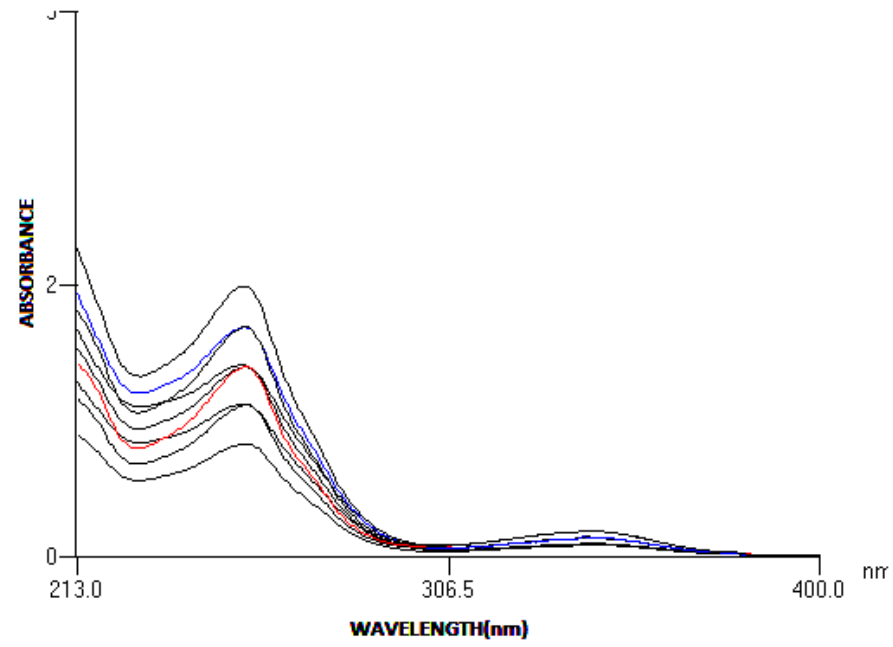

Figure 3 Prediction spectra of Diacerein and Celecoxib

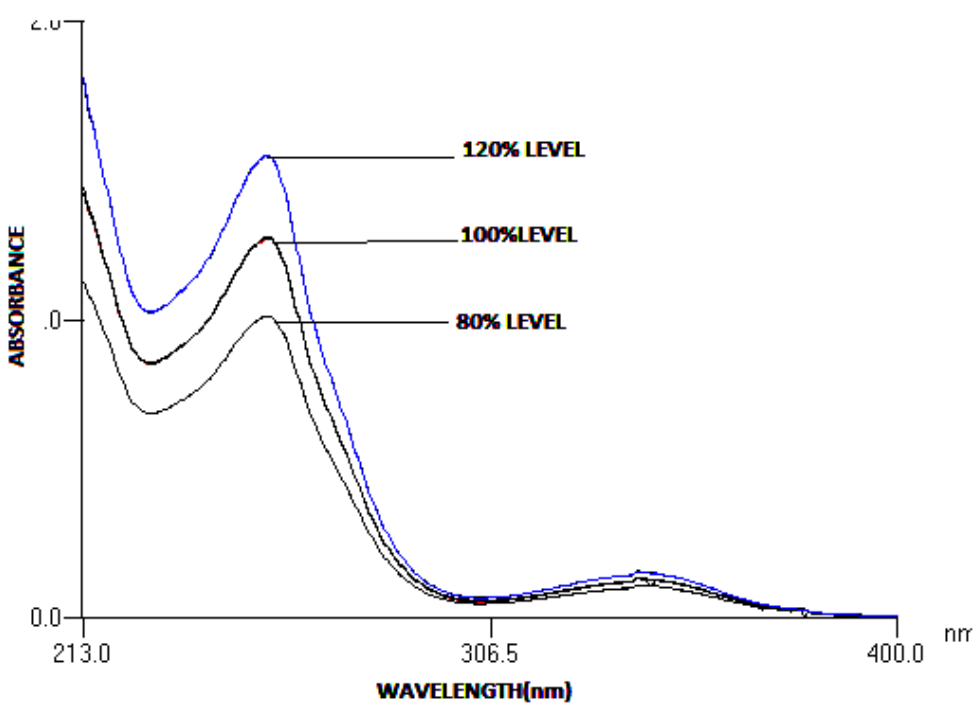

Figure 4 Recovery spectra of Diacerein and Celecoxib

\section{RESULTS \& DISCUSSIONS}

The absorption spectra of DIA and CELE solutions in methanol recorded between 225 - $288 \mathrm{~nm}$ were shown in Figure 1. The two drugs show an overlap in their absorption.

\section{Experimental design of sample sets}

Calibration and test sets for two component systems were designed according to factorial principle five-level factorial design was used to produce a calibration set (Training step) of 25 samples. Calibration spectra are shown in Figure 2. A three-level set was derived to produce a prediction set (Validation step) of nine samples. Prediction spectra are shown in Figure 3.The compositions of the used calibration and Validation sets are summarized in Tables $1 \& 2$ respectively.

\section{Selection of optimum number of factors and the spectral} region

The most commonly employed validation criterion is to divide the dataset into two subsets, a calibration set and a validation set. The calibration model is calculated using the calibration set. Then, the root mean square errors of calibration and validation, RMSEC - root mean square error of calibration and RMSEP - root mean square error of prediction, are calculated using the calibration model under investigation to predict the samples in the calibration set and validation set, respectively. The results are presented in Table 3.

\section{Market Sample Analysis (Assay)}

The proposed PLS and PCR methods were applied to the simultaneous determination of DIA and CELE in commercial capsules. Determination of six replicates was made. Satisfactory results were obtained for each drug in good agreement with the label claims. The results are presented in Table 4.

\section{Precision}

The method was found to be precise with six sample preparations for the quantification of DIA and CELE. The precision and intermediate precision variations were calculated in terms of relative standard deviation and the 
results were found to be less than $2.0 \%$ and the results are presented in Table 5.

\section{Recovery Studies}

To check the validity of the proposed methods, recovery studies were carried out by addition of the standard to the pre-analysed formulation. (Standard addition technique) Recovery spectra are shown in Figure 4 and the results are presented in Table. 6.

\section{CONCLUSIONS}

The most striking features of spectrophotometric method are its simplicity and rapidity without requiring time-consuming sample preparation. Chemometric calibration techniques in spectral analysis are widely used in quality control of drugs in mixtures and multi- component pharmaceutical formulations with overlapping spectra, as separation procedures in the drug determinations are not required. A comparative study of the use of PLS and PCR for the simultaneous spectrophotometric determination of diacerein and celecoxib has been accomplished.

High percentage of recovery shows that the methods are free from interference of the excipients used in the commercial formulation. Results also showed that the developed methods can be applied to a routine analysis, quality control of mixtures and commercial preparations containing these drugs.

\section{ACKNOWLEDGEMENT}

The author thanks our management of C.L Baid Metha college of Pharmacy and Ideal Analytical Research Institution, Pondicherry for their Instrumental support of this investigation.

\section{REFERENCES}

1. Oneil MJ, Heckelman PE. Koch CB, In: The Merck Index, 14th ed., Whitehouse station, NJ,Merck and Co Inc., 2006.p. 503.

2. Toegel, S, Huang, W, Piana, C, Unger,M, Wirth M, Goldring MB.BMC Molecular Biology, 2007.p. 8, 13.

3. Tive L. Rheumatology 39 Themed issue on Comborbidities in Rheumatic Diseases.2000. p. 21-28.

4. Janhavi Rao, Kanchan Chauhan, Mahadik K. R, Kadam S. S.A stability-indicating high performance liquid chromatographic method for the determination of diacerein in capsules. Indian J Pharm Sci.2009;71(1): 24 29. http://dx.doi.org/10.4103/0250-474X.51946

5. Narendra Kumar Nyola, Naresh Kalra.Spectrophotometric determination of diacerin in bulk and pharmaceutical formulation. Int J Pharm Biomed Sci.2010; 1(4):202-07.

6. Purnima Hamrapurkar, Priti Patil, Masti Desai, Mitesh Phale, Sandeep Pawar.Stress degradation studies and development of a validated stability- indicating-assay-method for determination of diacerein in presence of degradation products. J young pharm. 2011;2(1):30-35.

7. Sarika Narade, Snehal Patil, Sharda Surve, Dhanashri Shete, Yogesh Pore. Development and validation of UV spectrophotometric method for the determination of diacerein in capsules. Digest J Nanomater Biostruc.2010;5(1):113 - 18 .

8. Sreejith K.R and Premalatha K,. Novel spectrophotometric methods for estimation of diacerein from formulations. Int J Res Biomed Sci.2011; 2 (3):992-99.

9. Frank Scho"nberger, Georg Heinkele, Thomas E. Mürdter, Stefanie Brenner, Ulrich Klotz, Ute Hofmann.Simple and sensitive method for the determination of celecoxib in human serum by high-performance liquid chromatography with fluorescence detection. J Chromatogr B. 2002;768:255-60. http://dx.doi.org/10.1016/S1570-0232(01)00588-8

10. Mei Zhang, Grant A. Moore, Sharon J. Gardiner, Evan J. Begg. Determination of celecoxib in human plasma and breast milk by highperformance liquid chromatographic assay. J Chromatogr B.2006;830: 24548. http://dx.doi.org/10.1016/j.jchromb.2005.10.048

11. Nageswara Rao R, Meena S, Nagaraju D, Raghu Ram Rao A. Development and validation of a reversed-phase liquid chromatographic method for separation and simultaneous determination of COX-2 inhibitors in pharmaceuticals and its application to biological fluids. J Biomed Chromatogr.2005;19(5):362-68. http://dx.doi.org/10.1002/bmc.458

12. Rose M.J, Woolf E.J, Matuszewski B.K. Determination of celecoxib in human plasma by normal-phase high-performance liquid chromatography with column switching and ultraviolet absorbance detection.J Chromatogr.2000; 738:377-85.

13. Saha R.N, Sajeev C, Jadhav P.R, Patil S.P, Srinivasan N. Determination of celecoxib in pharmaceutical formulations using UV spectrophotometry and liquid chromatography. J Pharmaceut Biomed.2002; 28:741-51. http://dx.doi.org/10.1016/S0731-7085(01)00678-1

14. Sherry Chow H.H, Nathan Anavy, Dawn Salazar, Denise H. Frank, David S. Alberts. Determination of celecoxib in human plasma using solidphase extraction and high-performance liquid chromatography.J Pharmaceut Biomed.2004; 34:167-174. http://dx.doi.org/10.1016/j.japna.2003.08.018

15. Srinivasu M.K, Lakshmi Narayana CH, Sreenivas Rao D, Om Reddy G.A. validated LC method for the quantitative determination of celecoxib in pharmaceutical dosage forms and purity evaluation in bulk drugs.J Pharmaceut Biomed.2000; 22:949-56. http://dx.doi.org/10.1016/S07317085(00)00303-4

16. Venkata V. Pavan Kumar, Menon C. A. Vinu, Addepalli V. Ramani, Ramesh Mullangi, Nuggehally R. Srinivas. Simultaneous quantitation of etoricoxib, salicylic acid, valdecoxib, ketoprofen, nimesulide and celecoxib in plasma by high-performance liquid chromatography with UV detection.J Biomed Chromatogr.2006;20(1):125-32. http://dx.doi. $\mathrm{rg} / 10.1002 / \mathrm{bmc} .539$

17. Vigneau E, Devaux M.F, Qannari E.M, Robert P.Principal component regression, ridge regression and ridge principal component regression in spectroscopy calibration. J Chemom.1997.p.239-49.

18. Brereton R, Chemometrics, Data Analysis for the Laboratory and Chemical Plant, Wiley, Chichester:2003.

Cite this article as:

Vijayageetha Ragupathy, Shantha Arcot. Simultaneous spectrophotometric determination of Diacerein and Celecoxib in capsules by chemometric methods. Int. Res. J. Pharm. 2013; 4(6):229-233 